\title{
The Relationship between Productivity and Firm's Performance: Evidence from Listed Firms in Vietnam Stock Exchange
}

\author{
Phong Anh NGUYEN ${ }^{1}$, Anh Hoang NGUYEN ${ }^{2}$, Thanh Phu NGO ${ }^{3}$, Phuong Vu NGUYEN ${ }^{4}$
}

Received: April 24, 2019 Revised: April 30, 2019 Accepted: June 18, 2019

\begin{abstract}
The study aims to examine the impact of productivity in addition to the policy of increasing the foreign investors' ownership rate on the performance of businesses which were listed on Vietnam's stock exchange market from 2010 to 2017. With the database of 3.961 observations, the study employs a statistical method - multiple regression to estimate the relationship between labor productivity, foreign ownership as well as other firm-level characteristics and firm performance. Research findings show that increasing labor productivity and increasing foreign ownership rates help increase firm performance. In addition, except for financial leverage, variables such as liquidity and firm size have positive effects on firm performance measured by Tobin's $Q$. These findings have theoretical contributions and practical implications for managers, investors and government in Vietnam. Managers should pay attention to improving labor productivity through employing incentive mechanisms, building a good working environment, investing in technology, etc. in order to enhance the firm performance. Investors could utilize the labor productivity and foreign ownership indicators to select stocks of good companies for investment. For Vietnamese government, relaxing the limit of foreign ownership and accelerating the divesting of State capital in Stateowned enterprises could help increase the investment scale of foreign investors and resulting in positive effects on the firm performance.
\end{abstract}

Keywords: Labour Productivity, Firm Performance, Tobin's Q, Foreign Ownership, Vietnam Stock Exchange.

JEL Classification Code: D24, G32, L25.

\section{Introduction}

Productivity and performance are important concepts and measures describing the successfulness of an organization.

1 First Author and Corresponding Author. Dean, Faculty of Banking and Finance, University of Economics and Law, Vietnam National University, Ho Chi Minh City, Vietnam [Postal Address: 669 National Highway 1A, Quarter 3, Linh Xuan Ward, Thu Duc District, Ho Chi Minh City, 700000 Vietnam].

Email: phongna@uel.edu.vn

2 Lecturer, Faculty of Banking and Finance, University of Economics and Law, Vietnam National University, Ho Chi Minh City, Vietnam. Email: anhnh@uel.edu.vn

3 Lecturer, Faculty of Banking and Finance, University of Economics and Law, Vietnam National University, Ho Chi Minh City, Vietnam. Email: thanhnp@uel.edu.vn

4 Director, Office of Educational Testing and Quality Assurance, University of Economics and Law, Vietnam National University, Ho Chi Minh City, Vietnam. Email: phuongnv@uel.edu.vn

(1) Copyright: Korean Distribution Science Association (KODISA)
This is an Open Access article distributed under the terms of the Creative Commons Attribution NonCommercial License (https://creativecommons.org/licenses/by-nc/4.0/) which permits unrestricted noncommercial use, distribution, and reproduction in any medium, provided the original work is properly cited.
Productivity is generally considered to be the efficient utilization of organizational resources (OECD, 2001). At firm level, productivity is a measure of a firm's ability to utilize its inputs to make as much output as possible.

It is common sense that there has to be a relationship between firm performance and productivity. The increase in productivity could lead to better profitability for the firm thanks to decreasing the cost per unit produced. However, this common knowledge is not enough in the modern business environment. There are examples where the firm enjoys high profitability (because of its capability to impose higher sale prices, or buy inputs in lower prices, or keep lower inventory levels) but productivity is poor and vice versa (Chew, 1989; Song, 1990). This relationship is not well-defined and fixed. There are many internal and external factors that can conceal this relationship. However, productivity improvement is one important approach among others to improve the firm performance. The increase of productivity means slowing down the progress of cost level, increasing price competition, enhancement in the ability to pay salaries, and money for the development of the firm and for environmental control. 
Krugman (1994, p.9) stated that "productivity isn't everything, but in the long run it is almost everything. A country's ability to improve its standard of living over time depends almost entirely on its ability to raise its output per worker". In today's global and competitive business environment, managers are increasingly under pressure to enhance the financial performance through improving the productivity of their companies. Since the crucial role of productivity as well as the unclear relationship between productivity and firm performance, one of this study's objectives is to investigate quantitatively the impact of productivity on firm financial performance. In fact, productivity and firm performance are important areas which have been well documented in literature (Alsughayir, 2013; Belay, Helo, Takala, \& Kasie, 2011; Crouzet, Parker, \& Pathak, 2014; Prakash, Jha, Prasad, \& Singh, 2017)

What differentiates our study from the rest is that we examine the relationship between firm performance and productivity in the context of relaxed regulations of foreign ownership by Vietnam government. In emerging countries like Vietnam, many studies have been implemented to draw attention on the effect of foreign ownership towards firm performance. Nevertheless, researchers have gained no consensus as to whether foreign capital has a positive or negative impact on firm performance.

There is a rich literature based on empirical studies concluding that the presence of foreign investors (particularly large foreign investors) in emerging stock markets helps to improve the firm's valuation and operating performance thanks to technology and management support, reducing capital expenditure, lessening agency cost and enhancing the productivity of listed firms (Douma, George, \& Kabir, 2006; Mitton, 2006; Ferreira \& Matos, 2008; Li, Nguyen, Pham, \& Wei, 2011; Roger \& Cheng-Yi, 2009). Some publications acknowledge that the productivity of companies whose capital comes from a developed economy is higher than the productivity of the companies with domestic capital (Aitken \& Harrison, 1999; Petkova, 2009). On the other hand, several empirical studies indicated that foreign ownership does not always yield better financial performance for domestic firms.

For example, Aitken and Harrison (1999) demonstrated on a sample of Venezuelan firms that only for small firms, foreign capital may help to improve the productivity. Konings (2001), in a transnational research conducted in Bulgaria, Romania and Poland, that the financial performance of companies with foreign capital is not better than the performance of companies with domestic capital. Foreign ownership has been found to have a negative impact on firm performance in Vietnam market due to the fact that foreign investors suffer from information asymmetry and they cannot play a monitoring role in corporate governance mechanisms. Since evidence on the impact of foreign ownership is mixed, further investigation is largely needed to investigate whether foreign ownership and its changes affect productivity and firm performance in a developing country like Vietnam.

Vietnam securities market is an interesting case for the study though Vietnam initiates the stock market later than many other developed countries. The first stock exchange was established in 2000 with only four listed companies. After 18 years of establishment and development, there are 731 firms listed on Vietnam stock exchange thanks to the interest of foreign investors and the privatization of stateowned enterprises. Nevertheless, in comparison with other countries, Vietnam stock market is still a frontier market with small size, low transparency and especially, poor shareholder protection mechanism (McGee, 2008; VCS, 2012). Besides, the market depends highly on institutional investors and foreign investors (VCS, 2012; Vo, 2015). For a long time, Viet Nam imposed restrictions on foreign ownership in domestically listed firms: up to $49 \%$ of the equity for the listed companies and up to $30 \%$ for the listed banks. However, passed in June 2015, the Decree No. $60 / 2015 / \mathrm{ND}^{-\mathrm{CP}^{2}}$ has allowed firms except for certain cases to be hold by foreign investors up to $100 \%$. Scrapping the cap of foreign ownership could have a positive impact on firm productivity and financial performance. Since foreign investors in Vietnam stock market have played an increasingly important role because of Decree 60, their impact on firm performance and productivity are becoming the interesting subject for research.

The study contributes to current body of literature on the subject of firm performance determinants in terms of productivity and foreign ownership. To the best of our knowledge, the study may be one of the uncommon studies

2 On 26 June 2015 the Government issued Decree No. 60/2015/ND-CP("Decree 60") amending and supplementing certain provisions of Decree No. 58/2012/ND-CP, on the detailing and guiding the implementation of selected provisions of this, and the Law on Securities. The Decree takes effect on September 1, 2015, and replaces Prime Minister Decision No. 55/2009/QD-TTg (15 April 2009) on the ratio of foreign investor's participating on the Viet Nam securities market. Previously, a foreign investor may purchase up to $49 \%$ of total shares of a listed company. According to Decree 60, this restriction will be removed and instead, the new restriction will be subject to the WTO commitments or other specific domestic laws (e.g., the 30\% cap in the banking sector). When there is no restriction under domestic law (e.g., for production companies, or distribution companies), then there is no limit for the foreign shareholding ratio. Decree 60 also addresses many other functions of foreign investment in public companies, along with other key aspects related to securities investment for foreigners. 
investigating whether productivity has an impact on firmlevel performance in Vietnam within the context of the change in foreign ownership restriction, according to Decree 60. We suppose that foreign investors, with advanced management experience and capital, could help domestic firms to improve firm productivity and performance.

The remainder of the paper is organized as follows. The literature and the hypotheses on the impact of productivity and foreign ownership on firm performance will be analyzed in the second section meanwhile the third section describes research methodology including the sample, data and model. The paper will be finalized with the empirical results and conclusion section.

\section{Literature Review and Hypothesis Development}

Empirical studies which attempt to identify determinants of firm performance could be classified in two main categories: internal variables and external variables. Internal determinants include variables which refer to management decisions, financial attributes and firm characteristics such as firm size, firm age, liquidity, capital structure, sales growth, working capital management, ownership structure and labour productivity (Al-Jafari \& Al-Samman, 2015; Asimakopoulos, Samitas, \& Papadogonas, 2009; Ito \& Fukao, 2006; Lee, 2009; Margaretha \& Supartika, 2016; Pratheepan, 2014; Yazdanfar, 2013). Studies which focus on external determinants imply that factors reflecting the market, industry and economic environment in which the firm operate have an impact on the firm profitability and performance (McGahan \& Porter, 2002). Since the scope of the study is limited by the objective, data availability as well as theoretical framework, our study emphasizes on internal determinants of listed firm performance consisting of firm productivity, foreign ownership, firm size, age, liquidity and leverage.

\subsection{Firm Performance: Concept and Measure}

The firm's success is basically explained by its performance over a certain period of time. Investors and stakeholders always take firm performance into consideration. Firm performance reflects the outcome, efficiency and effectiveness of the organization activity. Firm performance could be considered under different perspective, including financial and nonfinancial performance. Our study examines firm performance with regard to financial aspect.

Financial performance measure could be classified into two categories including accounting-based measurement and marketing-based measurement. Accounting-based measures are generally considered as indicator of the firm profitability in short term such as Return on Asset (ROA) (Asimakopoulos et al., 2009; Margaretha \& Supartika, 2016; O`Connell \& Cramer, 2010; Pratheepan, 2014; Stierwald, 2010; Yazdanfar, 2013), Return on Equity (ROE) (Obiyo \& Lenee, 2011; Lee, 2009). On the other hand, market-based measurement indicates long term expectations of shareholders regarding firm outcome in the future, which is based on the past and current performance of firms (Nakano \& Nguyen, 2012). Market-based measures are composed of Tobin's Q (Hu, Tam, \& Tan, 2010; O`Connell \& Cramer, 2010); Market Value Added (Abdullah, Shah, \& Hassan, 2008; Kula, 2005), Market-to-Book Valued Added (Yawson, 2006) and others.

This study employs Tobin's $Q$ as a market-based measure of performance and examines how it is affected by productivity, foreign ownership and other firm-level characteristics. Tobin's $Q$ can be calculated as the ratio of the market capitalization plus total debt divided by total asset of the company. Firms with a $Q$ ratio of greater than 1.0 are able to create more values by using available resources effectively meanwhile those with a q value of less than 1.0 are associated with poor utilization of available resources. Tobin's $Q$ has been accepted as an important measure of firm performance since it shows the value created for investors. Instead of indicating past performance of the firm like accounting-based measures, Tobin's $Q$, as mentioned above, could be used to evaluate long-term performance as well as firm future growth. A higher value of Tobin's Q implies higher economic performance (Abbadi \& Abu-Rub, 2012; La Porta, Lopez-de-Silanes, Shleifer, \& Vishny, 2002; Wernerfelt \& Montgomery, 1988).

\subsection{Firm Performance and Productivity}

Productivity implies the relationship between output and input over the same period of time (Mohanty \& Rastogi, 1986). However, since the firm often employs a bundle of resources or input such as labour, capital, material, energy and others to produce output, there are several ways of defining and measuring productivity (Prakash et al., 2017). Partial productivity measures like labour productivity and capital productivity indicate the ratio of total output to one class of input. Among partial productivity measures, labour productivity is the best-known type (OECD, 2001). It is crucial since it is closely related to 'per capita income' and the 'standard of living'. Moreover, according to the OECD Manual (2001), this type of measurement is easy and readable. In this study, we employ labour productivity measures to investigate its impact on firm performance in the context of the change in foreign ownership. Specifically, 
labour productivity is computed by total sales per employee, similar to Lemonakis, Vassakis, Garefalakis, and Partalidou (2016) and Aljinović Barać and Muminović (2013).

Regarding the productivity-performance link, previous empirical studies acknowledged that productivity is the key variable determining profitability and leading to performance improvement for corporations (Agiomirgianakis, Voulgaris, \& Papadogonas, 2006; Prakash et al., 2017; Salman \& Yazdanfar, 2012; Stierwald, 2010). For instance, Prakash et al. (2017) through collecting primary data from manufacturing firms in India explored that there exists an interrelationship among productivity, quality and business performance. Similarly, Yazdanfar (2013) applied unrelated regression on 12,530 non-financial firms in Sweden to investigate the variables effecting firm profitability. The findings disclosed that beyond firm size, growth, lagged profitability, productivity has a positive impact on firm profitability. By the same token, the study by Salman and Yazdanfar (2012) also revealed that productivity has a positive large effect with firm financial performance which is measured by ROA. In a like manner, Stierwald (2010) employed the random and fixed effect regression on 961 large Australia firms for the period 1995-2005 to investigate the determinants of profitability. The results asserted that productivity is one of key variables explaining firm profitability. Likewise, Agiomirgianakis et al. (2006) examined data of 3,094 Greek manufacturing firms to identify the key indicators of firm performance. The authors concluded that employee productivity, firm size, and firm age have a statistically positive relationship with firms' ROA. Based from the previous research, the following hypothesis is formulated:

\section{$\mathbf{H}_{1}$ : A firm's productivity positively influences its performance.}

\subsection{Firm Performance and Foreign Ownership}

With respect to the relationship between firm performance and foreign ownership, though there is a rich body of literature on this link, the study results do not have a clear consensus. On the one hand, many studies show a positive correlation between foreign ownership and firm performance (Choi, Park, \& Hong, 2012; Drakos \& Bekiris, 2010; Khanna \& Palepu, 2000; Ongore, 2011; Phung \& Mishra, 2015; Roger \& Cheng-Yi, 2009). For instance, Phung and Mishra (2015) utilized 2,744 firm-year observations to examine the effect of ownership structure on performance of listed firms on Vietnam stock exchange. The author confirmed that firm performance increases with an increase of foreign ownership and suggested that policy makers should encourage foreign ownership and widely dispersed state ownership in firms. Choi et al. (2012) investigated the impact of foreign board membership on the value of Korean firms and found that foreign ownership is positively related to firm value, suggesting that an increase in foreign ownership will enhance firm value due to independent monitoring over controlling shareholders. Ongore (2011) inspected the influence of different types of ownership on firm performance in Kenya. He revealed that while state ownership has a negative impact, foreign ownership has a significantly positive impact on firm performance. Roger and Cheng-Yi (2009) found that foreign institutional equity ownership is significantly associated with increased firm R\&D expenditures and also with improved firm performance. Khanna and Palepu (2000) with the panel data of 1004 private sector listed firms found that foreign ownership has a positive impact on firm performance measured by Tobin's $Q$.

On the other hand, several articles showed that there is no association between firm performance and foreign ownership ratio (Chen, Sun, Tang, \& Wu, 2011; Ford, Rork, \& Elmslie, 2008; Gedajlovic, Yoshikawa, \& Hashimoto, 2005; Kumar, 2004; Welch, 2003). For example, Chen et al. (2011) and Ford et al. (2008) reported that the existence of foreign capital in the U.S firms not only does not help to improve the firm performance but lessen the firm profitability as well. Similarly, when evaluating the impact of foreign institutional ownership on Japanese manufacturing firms, Gedajlovic et al. (2005) concluded that there exists no relationship between foreign ownership and firms' ROA. Kumar (2004) also explored that foreign ownership has no influence on firm performance measured by ROA and ROE for an unbalanced panel data of 2,478 listed manufacturing firms in India.

In general, foreign ownership, especially large institutional foreign owners in emerging market often positively affects firm performance since foreign firms have advantages over the domestic firms in terms of access to technologies and better management. Therefore, the following hypothesis is formulated:

$\mathbf{H}_{2}$ : Foreign ownership influences firm performance in a
positive way.

\subsection{Firm Performance and Other Firm-Level Characteristics Determinants}

Beside productivity and foreign ownership, performance of the firm could be affected by multiple factors. However, based on the relevant empirical studies, we consider several firm-level characteristics as control variables in the model, including firm size, firm age, leverage and liquidity.

In respect of firm size, a variety of researches argue that average cost of operating a small business is higher than that of large firms (Agiomirgianakis, Magoutas, \& 
Sfakianakis, 2013; Nunes, Serrasqueiro, \& Sequeira, 2009). In other words, it is likely that large firms would have higher level of performance comparing with small ones, primary because of economy of scale. Besides, resource-basedview (RBV) theory infers that large enterprises have more opportunities to access capital and technology. Lots of studies confirmed the positive association between firm size and firm financial performance (Agiomirgianakis et al., 2013; Asimakopoulos et al., 2009; Nunes et al., 2009; Stierwald, 2010). Firm size can be measured by different proxies, such as assets, sales and employees. In this study, firm size is measured as the logarithm of the firm's book value of total assets. We expect the positive relationship between firm size and firm performance.

Concerning firm age, RBV explains that older companies can potentially acquire more resources such as information, experience, networks, access to finance and better reputation (Autio, 2005). As a result, the older the firm is, the better performance the firm enjoys. However, empirical researches reported that firm age can have a positive and a negative influence on firm performance. While several studies found that firm age and performance are positively correlated (Autio, 2005; Ito \& Fukao, 2006) other articles indicated a significantly negative relationship between them (Mehari \& Aemiro, 2013; Salman \& Yazdanfar, 2012; Yazdanfar, 2013). In this study, we use the number of years since the firm's established year as the measure for firm age. According to the RBV, firm age is expected to have positive impact on firm performance.

With regard to the linkage of financial leverage and firm performance, empirical evidences provide mixed and contradictory results. Specifically, the studies of Margaritis and Psillaki (2010) and Perger and Bonaccorsi (2006) conducted in the United States and France found that a higher debt ratio is associated with higher firm performance because use of more debt reduces agency costs of equity or encourages managers to act more in the shareholders' interests. However, Pratheepan (2014), Abor (2005) and Chhibber and Majumdar (1999), studying in Sri Lanka, Romania, Ghana, South Africa and India respectively found a negative effect of leverage on firm performance. It appears that the role of debt as a monitoring channel to improve firm performance is not considerable in emerging markets. Similar to the studies of Le and Phan (2017), Phung and Le (2013) which indicated that all debt ratios have significantly negative relation to firm performance in Vietnam, our study expect to find a negative relationship between leverage and firm performance.

Finally, as to liquidity which represents firm's ability to settle its short-term maturing obligations within one year, lots of studies recognized a positive impact of liquidity on firm financial performance in various countries and economic sectors (Boadi, Antavi, \& Lartey, 2013; Goel, Chadha, \& Sharma, 2015; Vintilă \& Nenu, 2016). On the other hand, several studies highlighted that liquidity has a negative and significant effect on firm performance because high liquidity implies a sign of wasted resources and lacking investment opportunities (Pratheepan, 2014; Vintilă \& Nenu, 2016). Our study utilizes the ratio of current assets and current liabilities as the proxy variable for firm liquidity. It is hypothesized that liquidity positively influences firm performance.

\section{Research Methodology}

\subsection{Sampling and Data}

Research objects of this study are the firms that listed on the stock exchanges of Vietnam, including Ho Chi Minh City Stock Exchange and Ha Noi Stock Exchange, with criterion as non-financial firms. We exclude financial firms since they have their own financial reporting systems and different regulations on foreign ownership as well. In addition, firms with book value of less than zero are also excluded. The data used in this study were collected from database of Fiinpro and Thomson Reuters for the 2010-2017 period. The data set includes detailed and audited financial statements, annual reports and other market-based financial data of listed firms such as foreign ownership, stock price and outstanding shares. Table 1 shows that the number of selected firms account for a large proportion of listed firms, in other words, the representativeness and the reliability of the research is ensured.

Table 1: Proportion of Research Sample towards Total Number of Vietnam Listed Firms

\begin{tabular}{|c|c|c|c|c|c|c|c|c|}
\hline Year & $\mathbf{2 0 1 0}$ & $\mathbf{2 0 1 1}$ & $\mathbf{2 0 1 2}$ & $\mathbf{2 0 1 3}$ & $\mathbf{2 0 1 4}$ & $\mathbf{2 0 1 5}$ & $\mathbf{2 0 1 6}$ & $\mathbf{2 0 1 7}$ \\
\hline $\begin{array}{c}\text { Number of } \\
\text { listed firms }\end{array}$ & 596 & 643 & 654 & 639 & 645 & 674 & 692 & 728 \\
\hline Sample size & 371 & 429 & 479 & 479 & 478 & 491 & 517 & 504 \\
\hline $\begin{array}{c}\text { Percentage } \\
(\%)\end{array}$ & 62.25 & 66.72 & 73.24 & 74.96 & 74.11 & 72.85 & 74.71 & 69.23 \\
\hline
\end{tabular}

Source: State Securities Commission of Vietnam

\subsection{Variables and Measurement}

Table 2 shows the summary of independent and dependent variables and their measurement.

Table 2: Variables and Measurement

\begin{tabular}{|l|c|l|c|}
\hline \multicolumn{1}{|c|}{ Dependent Variable } & \multicolumn{1}{|c|}{ Measurement } & $\begin{array}{c}\text { Expected } \\
\text { Sign }\end{array}$ \\
\hline $\begin{array}{l}\text { Firm performance } \\
\text { (Tobin's Q) }\end{array}$ & Tobin'Q & $\begin{array}{l}\text { Tobin'Q= } \\
\text { (MVofEquity }+ \text { BVof Debt })\end{array}$ & \\
\hline
\end{tabular}




\begin{tabular}{|c|c|c|c|}
\hline \multicolumn{4}{|c|}{ Independent Variables } \\
\hline $\begin{array}{l}\text { (Labor) Productivity } \\
\text { (mil. VND per } \\
\text { employee) }\end{array}$ & Lpro & $\begin{array}{l}\text { Lpro }= \\
\frac{\text { TotalSales }}{\text { AverageNumberofEmployees }}\end{array}$ & + \\
\hline $\begin{array}{l}\text { Foreign ownership } \\
(\%)\end{array}$ & Foreign & $\begin{array}{l}\text { the aggregate number of } \\
\text { shares held by foreign } \\
\text { investors in the listed } \\
\text { firms at the end of year }\end{array}$ & + \\
\hline $\begin{array}{l}\text { Firm size (Total } \\
\text { asset) }\end{array}$ & Lnta & $\begin{array}{l}\text { Natural logarithm of total } \\
\text { asset }\end{array}$ & + \\
\hline Firm age & Age & $\begin{array}{l}\text { the number of years } \\
\text { since the firm's } \\
\text { established year until } \\
\text { December } 2017\end{array}$ & + \\
\hline Firm leverage (\%) & Lev & Lev $=\frac{\text { TotalDebt }(\text { bil.VND })}{\text { TotalAsset }(\text { bil.VND })}$ & - \\
\hline Firm liquidity (\%) & Liq & $\begin{array}{l}\text { Liq }= \\
\frac{\text { CurrentAssets(bil.VND) }}{\text { CurrentLiabilities(bil.VND) }}\end{array}$ & + \\
\hline
\end{tabular}

\subsection{Model Specification}

This study employs a statistical method - multiple regression to estimate the impact of several independent or explanatory variables on the dependent variable. The regression model for the complete sample is as follows:

$$
\begin{aligned}
\text { Tobin' }_{i, t}= & \alpha+\beta_{1}{ }^{*} \text { Ipro }_{i, t}+\beta_{2}{ }^{*} \text { foreign }_{i, t}+\beta_{3}{ }^{*} \operatorname{lnta}_{i, t} \\
& +\beta_{4}{ }^{*} \text { age }_{i, t}+\beta_{5}{ }^{*} \operatorname{lev}_{i, t}+\beta_{6}{ }^{*} \operatorname{liq}_{i, t}+\varepsilon_{i, t}
\end{aligned}
$$

\section{Findings and Discussion}

Table 3 below describes the values of variables in the research model. The value of the Tobin' $Q$ variable has an average value of 1.0632 and has Min and Max values of 0.1899 and 9.0439 , respectively. In general, the average value of firm performance (Tobin'Q) this period is good (because it is greater than 1), but there are still many businesses with this value of less than 1. Labor productivity variable Ipro has an average value of 8.3012, meaning that on average 1 employee generates revenue of over 8.3 billion VND a year, but the minimum value is also recorded low at only 0.74 million VND per employee in a year.

The difference between the highest and lowest values of labor productivity is very large, leading to a very high standard deviation. For the rate of foreign ownership, its average value in general is still quite low at only $9.11 \%$. Many businesses still do not have foreign ownership, so this rate is recorded $0 \%$. After 2015 many firms have actively raised foreign ownership ratio but the highest value is only $64.62 \%$. The firm size variable is measured by logarithm of total assets with an average value of 26.95 and has a negligible difference in Min and Max values due to logarithmic variables.
The variable of financial leverage has an average value of less than $50 \%(49.81 \%)$, many businesses use less debt (the min value is close to zero), while some businesses use high debt (the max value is 1.24). The businesses' liquidity has an average value of 2.18 , a good liquidity level, while the difference between the highest and lowest values is also very large. Finally, the age variable (Age) is a variable computed from the year of establishment, has an average value of over 9 years. Some newly established and listed businesses should have relatively low age (2 years), while there are also long established businesses (40 years).

Table 3: Descriptive Statistics of Variables

\begin{tabular}{|c|c|c|c|c|c|}
\hline Variable & Obs & Mean & Std. Dev & Min & Max \\
\hline Tobin'Q & 3961 & 1.0632 & 0.5215 & 0.1899 & 9.0439 \\
\hline Inta & 3961 & 26.9543 & 1.4654 & 23.0265 & 31.9220 \\
\hline foreign & 3961 & 0.0911 & 0.1305 & 0.00 & 0.6462 \\
\hline lev & 3961 & 0.4981 & 0.2233 & 0.0026 & 1.2409 \\
\hline liq & 3961 & 2.1831 & 2.5990 & 0.1008 & 35.3321 \\
\hline age & 3961 & 9.8744 & 3.8974 & 2 & 40 \\
\hline Ipro & 3961 & $8,300.54$ & $97,352.48$ & 0.7432 & $2,970,878.54$ \\
\hline \\
Source: Calculated by Stata based on calculated data from Fiinpro \\
and Thomson Reuters
\end{tabular}

Table 4 describes the correction matrix of variables in the model. In general, the correlation coefficients of variables are low at acceptable levels. The correlation statistics shows that the performance variable measured by Tobin'Q with other variables is mostly positively correlated, except for the leverage variable.

Table 4: Correlation Matrix of Variables

\begin{tabular}{|c|c|c|c|c|c|c|c|}
\hline & Tobin'Q & Inta & foreign & lev & liq & age & Ipro \\
\hline Tobin'Q & 1.0000 & & & & & & \\
\hline Inta & 0.1328 & 1.0000 & & & & & \\
\hline foreign & 0.2641 & 0.2987 & 1.0000 & & & & \\
\hline lev & -0.1600 & 0.3471 & -0.2093 & 1.0000 & & & \\
\hline liq & 0.1588 & -0.1778 & 0.1086 & -0.5551 & 1.0000 & & \\
\hline age & 0.0531 & 0.0123 & 0.1591 & -0.1110 & 0.0953 & 1.0000 & \\
\hline Ipro & 0.0555 & 0.0770 & 0.0975 & 0.0145 & -0.0195 & -0.0155 & 1.0000 \\
\hline
\end{tabular}

Source: Calculated by Stata based on calculated data from Fiinpro and Thomson Reuters

Table 3 displaying descriptive statistics of the variables indicates a large difference between the highest and lowest values in the variables. the result of the diagnosis of the model is vulnerable to the variance change phenomenon. Test results show that the model is changed by variance. In order to overcome the variance change, the authors used robust option in Stata. In addition, to examine the difference in impacts of pre- and post-regulation on increasing foreign ownership, we generated the results by years (see Table 5). 
Table 5: Regression Results from the Model

\begin{tabular}{|c|c|c|c|}
\hline & \multicolumn{1}{|l|}{ Coef } & \multicolumn{1}{l|}{ t-test } & P-value \\
\hline Const & 0.2291 & 1.10 & 0.27 \\
\hline Inta & 0.0417 & 5.14 & $0.00\left(^{*}\right)$ \\
\hline foreign & 0.7391 & 7.40 & $0.00\left(^{*}\right)$ \\
\hline lev & -0.2361 & -3.82 & $0.00\left(^{*}\right)$ \\
\hline liq & 0.0190 & 2.31 & $0.021\left(^{* *}\right)$ \\
\hline age & -0.0007 & -0.36 & 0.71 \\
\hline Ipro & 1.8802 & 1.69 & $0.091\left(^{* *}\right)$ \\
\hline 2010 & -0.1561 & -3.87 & $0.00\left(^{*}\right)$ \\
\hline 2011 & -0.4410 & -11.66 & $0.00\left(^{*}\right)$ \\
\hline 2012 & -0.4135 & -10.75 & $0.00\left(^{*}\right)$ \\
\hline 2013 & -0.3519 & -8.99 & $0.00\left(^{*}\right)$ \\
\hline 2014 & -0.2653 & -6.53 & $0.00\left(^{*}\right)$ \\
\hline 2015 & -0.2464 & -5.53 & $0.00\left(^{*}\right)$ \\
\hline 2016 & -0.2409 & -5.41 & $0.00\left(^{*}\right)$ \\
\hline 2017 & -0.2193 & -4.53 & $0.00\left(^{*}\right)$ \\
\hline
\end{tabular}

Source: Calculated by Stata based on calculated data from Fiinpro and Thomson Reuters

Note: $\left({ }^{*}\right),\left({ }^{* *}\right)$ and $\left({ }^{* * *}\right)$ are corresponding to the $1 \%, 5 \%$ and $10 \%$ significance levels

The regression results are quite similar to the correlation analysis of the variables in Table 5 , most of the variables in the model have a positive impact on the performance variable Tobin'Q, except that financial leverage and age variables have a reverse impact on performance (firm age variable is not statistically significant).

The labor productivity variable (Lpro) has a positive beta and with the highest impact on firm performance. Increasing labor productivity of 1 million VND / year may help improve the performance Tobin' $Q$ by 1.88. This finding is consistent with $\mathrm{H} 1$ (alternative) hypothesis, and consistent with the research of Prakash et al. (2017), Salman and Yazdanfar, (2012), Stierwald (2010) and Yazdnafar (2013).

Next is the variable of foreign ownership also has a positive impact on firm performance. If this ratio increases by $1 \%$, firm performance will increase by 0.74 . The dummy results by year also show that in 2015 when the percentage of foreign ownership there are also similar results, meaning that from 2015 onwards, the firm performance has improved markedly. This finding is consistent with the hypothesis $\mathrm{H} 2$, and concurs with the studies of Choi et al. (2012), Drakos and Bekiris (2010), Ongore (2011), Phung and Mishra (2015) and Roger and Cheng-Yi (2009).

The firm size variable has a positive impact on firm performance, which is consistent with the theory of firm size and competitive advantage as discussed in previous empirical research (Agiomirgianakis et al., 2013; Stierwald, 2010; Asimakopoulos et al., 2009; Nunes et al., 2009). In other words, in the context of other factors that remains constant when businesses increase in size, creating a cost advantage which helps to improve firm performance. Large businesses often have access to diverse resources such as capital and technology than small businesses; therefore, return on investment and firm performance are also higher.

For the liquidity variable, research results show that high liquidity also increases firm performance. This result is similar to some previous studies (Goel et al., 2015; Vintilă \& Nenu, 2016). In the financial markets where the problem of information asymmetry is as common as Vietnam, the fact that firms maintain a high liquidity ratio can help them avoid expenses related to equity such as registration fees, underwriting fees and other legal costs (Vintilă \& Nenu, 2016). According to Vintilă and Nenu (2016) the information asymmetry and cost of capital are positively correlated. Thus, if firms maintain sufficient liquidity to finance working capital or even fixed assets, the cost of capital will decrease significantly, thereby increasing firm performance.

Unlike the other variables, financial leverage is the only variable in the model that has a negative impact on firm performance. In Vietnam, perhaps the benefits from the tax shield of debt use cannot compensate for the cost of financial distress. This finding implies that in the context of volatile financial market conditions, unstable interest rate, great information gap, businesses using high debts may easily lead to risks. Reconciling the results described in Table 3 shows that on average, businesses use debt of $50 \%$ which is relatively high, so the possibility of increasing debt increases the risk for investors.

\section{Conclusion}

With the aim is to examine the impact of labor productivity and foreign ownership rate on the performance of listed companies on the Vietnam stock market, the research findings indicate that that in addition to factors such as firm size, financial leverage, and liquidity, labor productivity and foreign ownership are the two most significant variables impacting the firm performance measured by Tobin's $Q$. The firm age variable has the negative impact on firm performance but is not statistically significant.

Research findings provide useful implications for administrators to improve firm performance. The results of this study indicate that businesses that want to improve or increase long-term performance should always pay attention to and improve labor productivity. Labor productivity can be increased by appropriate incentive mechanisms and by building a good working environment for employees. Moreover today, under the influence of technology revolution, many businesses invest in technology to reduce management and operation costs, labor costs and the number of employees. This contributes to increasing customers through enhancing utility or convenience 
communication has contributed to promoting labor productivity, increasing market prices and improving Tobin's $Q$ for businesses.

The study also found that the Vietnamese government's policy of removing the foreign ownership room is necessary in line with the integration trend and contributes to increasing labor productivity and performance when foreign investors bring benefits other than capital such as technology and management experience. In addition, to enhance firm performance, it is also necessary to pay attention to improving liquidity, restructuring loans in the previous period with high interest rates and should not increase debt in the volatile financial market.

\section{Reference}

Abbadi, S. M., \& Abu-Rub, N. (2012). The effect of capital structure on the performance of Palestinian financial institutions. British Journal of Economics, Finance and Management Sciences, 3(2), 99-100.

Abdullah, M. S., Shah, S. Z. A., \& Hassan, A. (2008). Impact of corporate governance on financial performance of firms: Evidence from Pakistan. The Business Review, 11, 282290.

Abor, J. (2005). The effect of capital structure on profitability: an empirical analysis of listed firms in Ghana. The Journal of Risk Finance, 6(5), 438-445.

Agiomirgianakis, G. M., Magoutas, A. I., \& Sfakianakis, I. (2013). Determinants of probability in the Greek tourism sector revisited: The impact of the economic crisis. Journal of Tourism and Hospitality Management, 1(1), 1217.

Agiomirgianakis, G., Voulgaris, F., \& Papadogonas, T. (2006). Financial factors affecting profitability and employment growth: The case of Greek manufacturing. International Journal of Financial Services Management, 1(2), 232-242.

Aitken, B. J., \& Harrison, A. E. (1999). Do domestic firms benefit from direct foreign investment? Evidence from Venezuela. American Economic Review, 89(2), 605-618.

Al-Jafari, M. K., \& Al-Samman, H. (2015). Determinants of profitability: Evidence from industrial companies listed on Muscat securities market. Review of European Studies, 7(1), 303-311.

Aljinović Barać, Ž., \& Muminović, S. (2013). The impact of capital investments on dairy processing industry features: Evidence from Slovenia, Croatia and Serbia. Mljekarstvo, 63(3), 140-149.

Alsughayir, A. (2013). The impact of quality practices on productivity and profitability in the Saudi Arabian dried date industry. American Journal of Business and Management, 2(4), 340-346.

Asimakopoulos, I., Samitas, A., \& Papadogonas, T. (2009). Firm-specific and economy wide determinants of firm profitability: Greek evidence using panel data. Managerial Finance, 35(11), 930-939.

Autio, E. (2005). Toward a theory of international new ventures. Journal of International Business Studies, 36(1), 9-19.

Belay, A. M., Helo, P., Takala, J., \& Kasie, F. M. (2011). Effects of quality management practices and concurrent engineering in business performance. International Journal of Business and Management, 6(3), 45-62.

Berger, A. N., \& Di Patti, E. B. (2006). Capital structure and firm performance: A new approach to testing agency theory and an application to the banking industry. Journal of Banking \& Finance, 30(4), 1065-1102.

Boadi, E. K., Antwi, S., \& Lartey, V. C. (2013). Determinants of profitability of insurance firms in Ghana. International Journal of Business and Social Research, 3(3), 43-50.

Chen, S., Sun, Z., Tang, S., \& Wu, D. (2011). Government intervention and investment efficiency: Evidence from China. Journal of Corporate Finance, 17(2), 259-271.

Chew, W. B. (1989). No-nonsense guide to measuring productivity, Harvard Business Review, 110-118.

Chhibber, P. K., \& Majumdar, S. K. (1999). Foreign ownership and profitability: Property rights, control, and the performance of firms in Indian industry. The Journal of Law and Economics, 42(1), 209-238.

Choi, S. B., Park, B. I., \& Hong, P. (2012). Does ownership structure matter for firm technological innovation performance? The case of Korean firms, Corporate Governance: An International Review, 20(3), 267-288.

Crouzet, B., Parker, W. D., \& Pathak, R. (2014). Preparing for productivity intervention initiatives. International Journal of Productivity and Performance Management, 63(7), 946-959.

Douma, S., George, R., \& Kabir, R. (2006). Foreign and domestic ownership, business groups, and firm performance: Evidence from a large emerging market. Strategic Management Journal, 27(7), 637-657

Drakos, A. A., \& Bekiris, F. V. (2010). Corporate Performance, Managerial Ownership and Endogeneity: A Simultaneous Equations Analysis for the Athens Stock Exchange. Research in International Business and Finance, 24(1), 24-38.

Ferreira, M. A., \& Matos, P. (2008). The colors of investors' money: The role of institutional investors around the world. Journal of Financial Economics, 88(3), 499-533.

Ford, T. C., Rork, J. C., \& Elmslie, B. T. (2008). Foreign direct investment, economic growth, and the human 
capital threshold: evidence from US states. Review of International Economics, 16(1), 96-113.

Gedajlovic, E., Yoshikawa, T., \& Hashimoto, M. (2005). Ownership Structure, Investment behaviour and Firm Performance in Japanese Manufacturing Industries, Organization Studies, 26(1), 7-35

Goel, U., Chadha, S., \& Sharma, A. K. (2015). Operating liquidity and financial leverage: Evidences from Indian machinery industry. Procedia-Social and Behavioral Sciences, 189, 344-350.

Hu, H. W., Tam, O. K., \& Tan, M. G. (2010). Internal governance mechanisms and firm performance in China. Asia Pacific Journal of Management, 27, 727-749. http://dx.doi.org/10.1007/s10490-009-9135-6.

Ito, K., \& Fukao, K. (2006). Determinants of the profitability of the Japanese manufacturing affiliates in China and regions: does localization of procurement, sales and management matter. The World Economy, 33(12), 16391671.

Kang, S. A., \& Chun, S. B. (2010). Characteristics of Firms Engaged in Real Activity-based Earnings Management: Evidence from Korea. Korean Accounting Review, 35(2), 35-70.

Khanna, T., \& Palepu, K. (2000). Emerging Market Business Groups, Foreign Intermediaries, and Corporate Governance. In Concentrated Corporate Ownership (pp. 265-294). Chicago, IL: University of Chicago Press.

Konings, J. (2001). The effects of foreign direct investment on domestic firms: Evidence from firm-level panel data in emerging economies. Economics of Transition, 9(3), 619633.

Krugman, P. R. (1994). The Age of Diminished Expectations: U.S. Economic Policy in the 1990s. Cambridge, MA: MIT Press.

Kula, V. (2005). The impact of the roles, structure and process of boards on firm performance: Evidence from Turkey. Corporate Governance, 13(2), 265-276.

Kumar, J. (2004). Does ownership structure influence firm value? Evidence from India, Journal of Entrepreneurial Finance and Business Ventures, 9(2), 61-93.

La Porta, R., Lopez-de-Silanes, F., Shleifer, A., \& Vishny, R. (2002). Investor protection and corporate valuation. Journal of Finance, 57(3), 1147-1170.

Le, T. P. V., \& Phan, T. B. N. (2017). Capital structure and firm performance: Empirical evidence from a small transition country. Research in International Business and Finance, 42, 710-726. Doi:10.1016/j.ribaf.2017.07.012.

Lee, J. (2009). Does size matter in firm performance? Evidence from US public firms. International Journal of the Economics of Business, 16(2), 189-203.
Lemonakis, C., Vassakis, K., Garefalakis, A., \& Partalidou, X. (2016). Manufacturing firms' performance and productivity: Evidence from North and South European, Scandinavian and Balkan Countries. Theoretical Economics Letters, 6(4), 789-797.

Li, D., Nguyen, Q. N., Pham, P. K., \& Wei, S. X. (2011). Large foreign ownership and firm-level stock return volatility in emerging markets. Journal of Financial and Quantitative Analysis, 46(4), 1127-1155.

Margaretha, F., \& Supartika, N. (2016). Factors affecting profitability of small-medium enterprises (SMEs) firms listed in Indonesia stock exchange. Journal of Economics, Business and Management, 4(2), 132-137.

Margaritis, D., \& Psillaki, P. (2010). Capital structure, equity ownership and firm performance. Journal of Banking \& Finance, 34, 621-632.

McGee, R. (2008). Corporate governance in Asia: a comparative study (Working Paper Series). Miami, FL: College of Business Administration, Florida International University.

Mehari, D., \& Aemiro, T. (2013). Firm specific factors that determine insurance companies'performance in Ethiopia. European Scientific Journal, 9(10). DOI: http://dx.doi.org/10.19044/esj.2013.v9n10p\%25p

Mitton, T. (2006). Stock market liberalization and operating performance at the firm level. Journal of Financial Economics, 81(3), 625-647.

Mohanty, R. P., \& Rastogi, S. C. (1986). An action research approach to productivity measurement. International Journal of Operations \& Production Management, 6(2), 47-61.

Nunes, P. J. M., Serrasqueiro, Z. M., \& Sequeira, T. N. (2009). Profitability in Portuguese Service Industries: A Panel Data Approach. The Service Industries Journal, 29(5), 693-707.

O'connell, V., \& Cramer, N. (2010). The relationship between firm performance and board characteristics in Ireland. European Management Journal, 28, 387-399. http://dx.doi.org/10.1016/j.emj.2009.11.002

Obiyo, O. C., \& Lenee, L. T. (2011). Corporate governance and firm performance in Nigeria. International Journal of Exclusive Management Research, 1(4), 1-12.

OECD (2001). Measuring Productivity, OECD Manual Measurement of Aggregate and Industry-Level Productivity Growth. OECD, Paris. Retrieved January 19, 2019 from www.sourceOECD.org.

Ongore, V. (2011). The relationship between ownership structure and firm performance: An empirical analysis of listed companies in Kenya. African Journal of Business Management, 5(6), 2120-8.

Petkova, N. (2009). Essays on firm ownership, performance and value. A dissertation paper, University of Michigan. 
Retrieved from http://deepblue.lib.umich.edu/bitstream/ 2027.42/62412/1/ npetkova_1.pdf.

Phung, D. N., \& Le, T. P. V. (2013). Foreign ownership, capital structure and firm performance: e=Empirical evidence from Vietnamese listed firms. IUP Journal of Corporate Governance, 12(2), 40-58.

Phung, D. N., \& Mishra, A. V. (2015). Ownership structure and firm performance: Evidence from Vietnamese listed firms. Australian Economic Papers, 55(1), 63-98. doi:10.1111/1467-8454.12056

Prakash, A., Jha, S. K., Prasad, K. D., \& Singh, A. K. (2017). Productivity, quality and business performance: an empirical study. International Journal of Productivity and Performance Management, 66(1), 78-91. Doi:10.1108/IJPPM-03-2015-0041

Pratheepan, T. (2014). A panel data analysis of profitability determinants: Empirical results from Sri Lankan manufacturing companies. International Journal of Economics, Commerce and Management, 2(12), 1-9.

Roger H. D., \& Cheng-Yi, S. (2009). Local effects of foreign ownership in an emerging financial market: Evidence from qualified foreign institutional investors in Taiwan. Financial Management, 38(3), 567-602.

Salman A. K. \& Yazdanfar D. (2012). Profitability in Swedish SME firms: A quantile regression approach. International Business Research, 5(8), 94-106.

Song, Y. K. (1990). A Performance measurement method which remedies the productivity paradox. Production and Inventory Management Journal, 31, 38-43.
Stierwald, A. (2010). Determinants of firm profitability-The effect of productivity and its persistence. Melbourne Institute of Applied Economic and Social Research, pp.125.

Viet Capital Securities (VCS). (2012). Strategy report: Vietnam prospective in 2012. Ho Chi Minh City, Vietnam: Viet Capital Securities.

Vintilă, G., \& Nenu, E. A. (2016). Liquidity and profitability analysis on the Romanian listed companies. Journal of Eastern Europe Research in Business \& Economics, 2016, 1-8.

Vo, X. V. (2015). Foreign ownership and stock return volatility-Evidence from Vietnam. Journal of Multinational Financial Management, 30, 101-109.

Welch, E. (2003). The Relationship between Ownership Structure and Performance in Listed Australian Companies. Australian Journal of Management, 28(3), 287-305.

Wernerfelt, B., \& Montgomery, C. A. (1988). Tobin's $Q$ and the importance of focus in firm performance. American Economic Review, 78, 246-250.

Yawson, A. (2006). Evaluating the characteristics of corporate boards associated with layoff decisions. Corporate Governance, 14(2), 75-85.

Yazdanfar, D. (2013). Profitability determinants among micro firms: Evidence from Swedish data. International Journal of Managerial Finance, 9(2), 150-160. 